DOI: 10.2478/atd-2022-0010

\title{
What are Turkish Preservice Science Teachers' Claims about Daily Life-Threatening Situations?
}

\author{
Handan Ürek - Mustafa Çoramık*
}

\begin{abstract}
Received: October 23, 2020; received in revised form: February 27, 2021;
\end{abstract} accepted: March 1, 2021

\begin{abstract}
:
Introduction: Science courses involve a wide range of content. The benefits of science education become clear when science is applied to daily life because science has the capability of raising the quality of life by eliminating a variety of problems. Accordingly, as technological advances are made, daily life applications are frequently refreshed and improved. Though such improvements aim to make contributions to human life, many points still need to be considered carefully. In this study, we wanted to address this issue from the perspective of preservice science teachers. The target of the present study therefore is to investigate the claims of preservice science teachers about daily life-threatening situations which can be explained within the scope of their scientific knowledge of physics, chemistry and biology. Thus, the study will introduce examples given by preservice teachers regarding everyday situations that endanger daily life, along with their reasons for providing these examples. It will also be possible in this way to determine situations that were not mentioned by the participants.

Methods: A qualitative study was conducted with a total of 153 third-year preservice science teachers studying in three different state universities in western Turkey. Data were collected with the help of a questionnaire consisting of three open-ended questions. Content analysis was utilized in the data analysis. The analysis results yielded themes and categories that the participants identified as daily life-threatening situations. An analysis was also made of why the participants chose to offer these particular examples.

Results: According to the results, the most common daily life-threatening situations identified by the participants were electric shock (68.6\%), which fell within the scope of their physics knowledge; not taking safety precautions while working with chemicals $(74.5 \%)$, falling within the scope of their chemistry knowledge; and damaging nature $(33.3 \%)$, which
\end{abstract}

\footnotetext{
* Handan Ürek, Balıkesir University, Necatibey Education Faculty, Balıkesir, Turkey; handanurek@balikesir.edu.tr

Mustafa Çoramık, Balıkesir University, Necatibey Education Faculty, Balıkesir, Turkey; mustafacoramik@balikesir.edu.tr
} 


\section{Acta Educationis Generalis \\ Volume 12, 2022, Issue 1}

fell within the scope of their biology knowledge. The participants generally referred to health and environmental problems as the reasons leading them to provide their examples.

Discussion: The study focused on the association of scientific knowledge with daily life, which is one of the aims of science education. The results indicated that preservice teachers associated their scientific knowledge with daily life-threatening situations at various levels. Also, the reasons they offered made connections with various health and environmental issues. In addition to the examples provided by the participants, several situations were seen to be ignored. Additionally, and in line with the literature, a few misconceptions were encountered in their explanations.

Limitations: The present study was limited to the findings obtained from three state universities in Turkey. Similar investigations might be conducted in different countries so that further comparisons may be made possible in this context.

Conclusion: To conclude, preservice science teachers were aware of various health and environmental issues with respect to the examples they offered. However, there were also gaps in their associations between scientific knowledge and daily life. The findings obtained from the present study might be used to design the content of courses (such as Environmental Science or Science Teaching Laboratory Practice) given in faculties of education, and to raise awareness among preservice teachers in this context.

Key words: science-daily life associations, scientific knowledge, preservice science teachers.

\section{Introduction}

Throughout history, the field of science education has provided various concepts for researchers to explore. One of these is scientific literacy (Deboer, 2000). As a result of scholarly discussions, Roth and Lee (2004) have indicated three assumptions related to this term: a) scientific literacy is an attribute of individuals; b) science is the paradigmatic mode for rational human conduct; and c) knowledge learned in school is transportable to life after school. One of the goals of science education is to teach and learn science that has a direct application to everyday living (Deboer, 2000). Accordingly, another term discussed in the field is science-technology-society (STS), which highlights connections to real life. Mansour (2009) indicates that teaching science within the STS paradigm is derived from both students and teachers working together cooperatively or from suggestions offered by students based on their interests and the life issues confronting them. Thus, various situations that exist in daily life are emphasized in the context of teaching science.

The benefits of science education become clear when it is applied to daily life because science raises the quality of life by eliminating a variety of problems. 


\section{Acta Educationis Generalis \\ Volume 12, 2022, Issue 1}

However, daily life activities might also lead to negative influences on human beings. Hence, individuals should possess awareness about possible dangers. This awareness is believed to be strongly connected to having sufficient scientific knowledge.

Unfortunately, science education is said to be in crisis (Chowdhury, 2013). Tytler (2007) explains four main aspects of this:

a) the evidence that students develop increasingly negative attitudes to science over the course of their secondary school years;

b) decreasing participation in post-compulsory science subjects, especially the "enabling" sciences of physics and chemistry, and higher mathematics;

c) a shortage of science-qualified people in the skilled workforce;

d) a shortage of qualified science teachers.

As can be seen above, one part of this negative situation related to science education has been attributed to science teachers. In this paper, we address elementary school science teachers. It might be stated that preservice science teachers are trained to teach the subjects of biology, chemistry and physics to middle school students. Their contribution to young students' attitudes and interests towards science is significant for this reason. However, Talanquer (2013) asserts that all prospective secondary school teachers and high school chemistry teachers do not recognize underlying themes and meaningful connections beyond content. Yet young students need to be taught science by considering underlying meanings. Researchers, policy makers and educators believe teachers to be important school-related influencers (Geršicová \& Barnová, 2018). Thus, preservice teachers' perceptions towards connecting concepts to everyday life with science are important in shaping the future of science education since this clearly will have an effect on the future of society.

There have been a number of learning theories in the literature that have not been fully successful in explaining and resolving issues related to learning due to the complex nature of human behavior and the differences between human beings (Mercan, Gürlen \& Köseoğlu, 2019). Recently, attempts have been made to overcome problems related to science education with the help of contextbased approaches where theoretical knowledge is closely related to daily life occurrences and events in contrast to rote learning. Context-based approaches are most frequently encountered in chemistry education (King, Bellocchi, \& Ritchie, 2008; Mandler, Mamlok-Naaman, Blonder, Yayon, \& Hofstein, 2012). In this kind of approach, the level of association between students' knowledge and daily life events is seen to be an indicator of the extent to which the education provided departs from rote learning (Cengiz \& Ayvac1, 2017). Science education is meaningful when students can translate their learning to their lives. Çepni, Ülger, and Ormanc1 (2017) express their view that associating science with daily life provides a meaningful learning of science concepts and the ability to use this knowledge in situations or problems that students encounter. The researchers determined that prospective science teachers believe that teachers 


\section{Acta Educationis Generalis \\ Volume 12, 2022, Issue 1}

play the most important role in helping students connect scientific knowledge with their everyday lives.

\section{Literature review}

In the literature, many works of research deal with the way students associate their scientific knowledge with daily life. Some address the issues of younger students. In their study, Taşdemir and Demirbaş (2010) investigated the ability of sixth- and seventh-grade students to utilize their scientific knowledge in solving the problems they encountered during their daily lives. Their results indicated that students mostly experienced difficulty in the unit related to matter whereas they were more successful in units related to light and sound. Brkich (2014) researched how fifth-grade students connected their real-life experiences with the content in earth science. The results showed that they were able to make direct observations of the content and made analogies when direct observations were not possible. Also, Cengiz and Ayvacı (2017) examined fifth-grade students' level of associating daily life events with the subject of changes of state. Their study revealed students' levels of partial understanding and misunderstanding.

There are several articles that deal with high school students in this context. In their study, Demircioğlu, Demircioğlu, Ayas and Kongur (2012) investigated levels of theoretical knowledge and application among tenth-grade students. The results implied that students were significantly more successful in terms of theoretical knowledge but also possessed insufficient understanding and misconceptions. In another study, Çimer (2012) identified one of the reasons that high school students experienced difficulty in learning biology was the fact that the topics covered in the courses were not associated with daily life.

It can be seen that there is more research conducted with university students studying in the faculties of education. This might be explained by the fact that it will be these students who will be taking on the role of teaching the students of the future about the associations between science and everyday life. In their study, Balkan-Kıyıcı and Aydoğdu (2011) reported that senior science teaching students connected their physics knowledge with everyday life at the highest level and that they formed associations to a lesser degree using their knowledge of chemistry and biology. In another study, Çepni et al. (2017) found that nearly all of the second-, third- and fourth-year science teaching students agreed on the importance of making a connection between scientific knowledge and everyday life. Also, Uğraş, Aydemir, and Asiltürk (2017) determined that senior science teaching students were more equipped with the scientific views that permitted them to connect their chemistry knowledge to daily life. Additionally, their attitudes towards teaching science showed a strong and statistically significant correlation with their association levels. At the same time, Yadigaroğlu, Demircioğlu, and Demircioğlu (2017) detected various problems related to the 


\section{Acta Educationis Generalis \\ Volume 12, 2022, Issue 1}

association of chemistry knowledge with daily life as well as various misconceptions among junior science teaching students.

The literature mentioned above pointed to several problems in the associations between scientific knowledge and everyday life made by students in different grades. On the other hand, context-based studies showed gains in learning (Demircioğlu, Demircioğlu, \& Çalık, 2009; Elmas \& Geban, 2016), learning retention (Demircioğlu et al., 2009; Kutu \& Sözbilir, 2011), and motivation (Kutu \& Sözbilir, 2011) among students.

\section{The rationale for the study}

As mentioned earlier, decreasing interest and attitudes of the students towards science makes it imperative for educators to find ways of getting students involved in their courses. Science courses involve a wide range of content that can be applied to daily life and these applications are frequently refreshed with technological improvements. Though those improvements aim to make contributions to human life, various points need to be considered carefully in this context. In this study we wanted to address this situation from the perspective of preservice science teachers. The present study thus targets the investigation of the claims of preservice science teachers about daily lifethreatening situations that can be explained in the context of their scientific knowledge (physics, chemistry and biology knowledge). Thus, the study will introduce examples given by preservice teachers regarding situations that endanger daily life, along with their reasons for choosing these cases. It will also be possible in this way to determine situations that were not mentioned by the participants.

It is thought that preservice science teachers should fully consider daily lifethreatening situations since they who will be the educators of young children in the future. The importance of preservice science teachers' association of scientific knowledge with daily life was also highlighted by Balkan-Kıyıcı and Aydoğdu (2011). A strong significant relationship was reported as well between preservice teachers' association of chemistry knowledge and science teaching attitudes (Uğraş et al., 2017). Unfortunately, the literature also indicated problems in students' association of scientific knowledge with daily life. The results of the present study are expected to make contributions to the field of science education in the context of the three branches of physics, chemistry and biology in order to make it possible to shape the contents of context-based science courses.

The research questions were as follows:

What were the Turkish preservice science teachers' examples and why did they choose these cases related to the daily life-threatening situations which they could explain within the scope of their:

- Physics knowledge?

- Chemistry knowledge? 


\section{Acta Educationis Generalis \\ Volume 12, 2022, Issue 1}

- Biology knowledge?

\section{Method}

\subsection{Study design}

The present study explored preservice science teachers' claims about daily lifethreatening situations that could be explained with scientific knowledge. In line with this aim, a qualitative approach was employed in the study. Qualitative research aims to provide detailed descriptions and interpretations and to comprehend the perspectives of the actors involved (Yıldırım \& Şimşek, 2016). Action research was thus conducted to learn what issues were related to the application of scientific knowledge in daily life. So, the intention of the study was to interpret the participants' perspectives from their reasons.

\subsection{Study group}

The study was conducted with the voluntary attendance of 153 preservice teachers studying in the science teaching programs of education faculties at three state universities located in the western part of Turkey. All of the participants were third-year students enrolled in four-year science teaching programs. The average age of the participants was 21. Eighty-eight (57.5\%) were female while $65(42.5 \%)$ were male students. Table 1 provides frequency and percentage distributions of the participants with respect to the university and gender factors.

Table 1

Participants' distribution with respect to university and gender

\begin{tabular}{lccc}
\hline & $\underline{\text { Female }}$ & $\underline{\text { Male }}$ & $\underline{\text { Total }}$ \\
University 1 & $29(19.0 \%)$ & $20(13.1 \%)$ & $49(32.0 \%)$ \\
University 2 & $27(17.6 \%)$ & $23(15.0 \%)$ & $50(32.7 \%)$ \\
University 3 & $32(20.9 \%)$ & $22(14.4 \%)$ & $54(35.3 \%)$ \\
Total & $88(57.5 \%)$ & $65(42.5 \%)$ & $153(100.0 \%)$ \\
\hline
\end{tabular}

The study group was formed via the purposeful sampling method. This method is based on selecting information-rich cases coinciding with the main aim of the study (Büyüköztürk, Kılıç Çakmak, Akgün, Karadeniz, \& Demirel, 2010). Criterion-based sampling, a type of purposeful sampling, was considered in the present study. Criterion-based sampling focuses on the examination of cases that meet several previously-determined criteria (Yıldırım \& Şimşek, 2016). These criteria are reported to be determined by the researchers or they might be based on a checklist. In this study, two criteria were considered in the formation of the study group by the researchers. Firstly, the participants were thought to be competent in the science branches of physics, chemistry and biology since they were taking related courses during their university education. Accordingly, the study investigates cases related to all of these three branches. Secondly, the 


\section{Acta Educationis Generalis \\ Volume 12, 2022, Issue 1}

participants were expected to be able to make reasonable claims in their third year because they had taken most of their field and field education courses by this time. The criticism might be made that their final year would have been more appropriate for this application, but graduation stress factors (business concerns, career decisions, etc.) are believed to be obstacles in obtaining fruitful responses in data gathering. The study was therefore designed in the structure described above.

\subsection{Data gathering instrument}

Data were collected with the help of an instrument consisting of three openended questions developed by the researchers. Open-ended questions allow researchers to handle the study subject in a flexible and open-ended manner (Yıldırım \& Şimşek, 2016). In each question, the students were asked to provide dangerous situation(s) that were encountered in daily life that involved physics, chemistry or biology. In addition, they were asked to provide explanations by giving reasons that would clarify their decision to choose the examples they gave. The students were asked to offer as many examples as they could, accompanied by reasonable explanations. The responses of the participants constituted the data of the study.

\subsection{Data analysis}

Data were analyzed with the help of the qualitative method of content analysis. The responses of the students for each branch were examined by the researchers in detail. In this process, codes were defined by the researchers which were derived from the study data (Hsieh \& Shannon, 2005). The procedure followed in the study analysis is demonstrated in Figure 1:

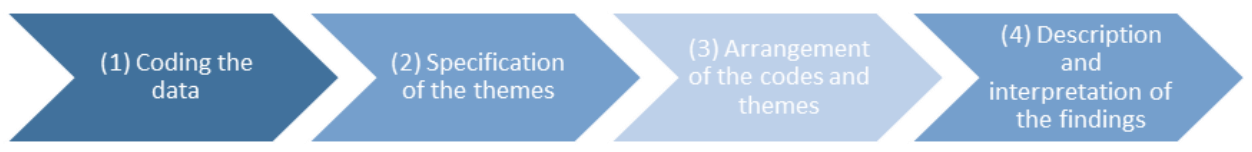

Figure 1. Steps of data analysis in qualitative research (Yıldırım \& Şimşek, 2016).

The participants' examples related to daily life-threatening situations were coded and classified in a meaningful manner. Afterwards, those codes were gathered under sub-categories and categories. Next, the categories were collected under main categories called themes (Çelik, Başer Baykal, \& Kılıç Memur, 2020). The same procedure was also conducted for the participants' explanations. The findings were tabulated to show the relative percentages of the categories.

Both researchers worked on the study data. They went on to identify the points they agreed and disagreed could be included in the same category. The reliability of data analysis was checked with the formula suggested by Miles and 


\section{Acta Educationis Generalis \\ Volume 12, 2022, Issue 1}

Huberman (1994). The calculation result indicates the reliability of data analysis when interrater consistency exceeds 70\% (Yıldırım \& Şimşek, 2016). After conducting careful discussions, the interrater consistencies were calculated to be $92.0 \%$ for the preservice teachers' examples and $95.0 \%$ for their reasons.

In the results of the analysis, several parts were marked with "*" which indicated misconceptions. At the same time, several preservice teachers were found to state irrelevant responses. Such responses were not presented in the tables but explained in the findings.

\section{Findings}

The findings of the study are presented in three sections that deal with physics, chemistry and biology.

\subsection{Findings in the context of physics}

Table 2 presents the preservice science teachers' examples and the reasons they offered for presenting the daily life-threatening situations that can be explained within the scope of physics knowledge.

Table 2

The Turkish preservice teachers' claims about daily life-threatening situations within the scope of physics knowledge

\begin{tabular}{|c|c|c|c|c|}
\hline Themes & $\frac{\text { Categories }}{\text { Electric shock }}$ & $\frac{\%}{68.6}$ & $\frac{\text { Because it might cause... }}{\text { Deaths and injuries }}$ & $\frac{\%}{68.6}$ \\
\hline \multirow{3}{*}{ Electricity } & \multirow{3}{*}{$\begin{array}{l}\text { Problems with electrical } \\
\text { items }\end{array}$} & \multirow{3}{*}{17.6} & Items breaking down & 9.8 \\
\hline & & & Fires & 3.9 \\
\hline & & & Injuries & 3.9 \\
\hline \multirow{3}{*}{ Friction } & $\begin{array}{l}\text { Not using winter tires in } \\
\text { cars during the winter }\end{array}$ & 5.9 & $\begin{array}{l}\text { Traffic accidents due to less } \\
\text { friction because of ice* }\end{array}$ & 5.9 \\
\hline & $\begin{array}{l}\text { Type of floor or ground } \\
\text { surface }\end{array}$ & 3.9 & $\begin{array}{l}\text { Injuries as the floor or ground } \\
\text { becomes slippery, especially } \\
\text { in winter }\end{array}$ & 3.9 \\
\hline & $\begin{array}{l}\text { Wearing leather-soled } \\
\text { shoes in winter }\end{array}$ & 1.9 & $\begin{array}{l}\text { Skidding and falling due to } \\
\text { less friction because of the } \\
\text { smaller surface areas of } \\
\text { leather-soled shoes* }\end{array}$ & 1.9 \\
\hline \multirow{3}{*}{$\begin{array}{l}\text { Motion- } \\
\text { Energy }\end{array}$} & $\begin{array}{l}\text { Falling of pulleys at } \\
\text { construction sites }\end{array}$ & 5.9 & \multirow{3}{*}{ Injuries } & \multirow{3}{*}{9.8} \\
\hline & $\begin{array}{l}\text { Squeezing an elastic } \\
\text { spring and releasing it }\end{array}$ & 1.9 & & \\
\hline & $\begin{array}{l}\text { Getting a hand caught in } \\
\text { a spinning wheel or } \\
\text { rotor }\end{array}$ & 1.9 & & \\
\hline Optics & Use of the wrong type & 3.9 & Harm to eyes & 3.9 \\
\hline
\end{tabular}




\section{Acta Educationis Generalis \\ Volume 12, 2022, Issue 1}

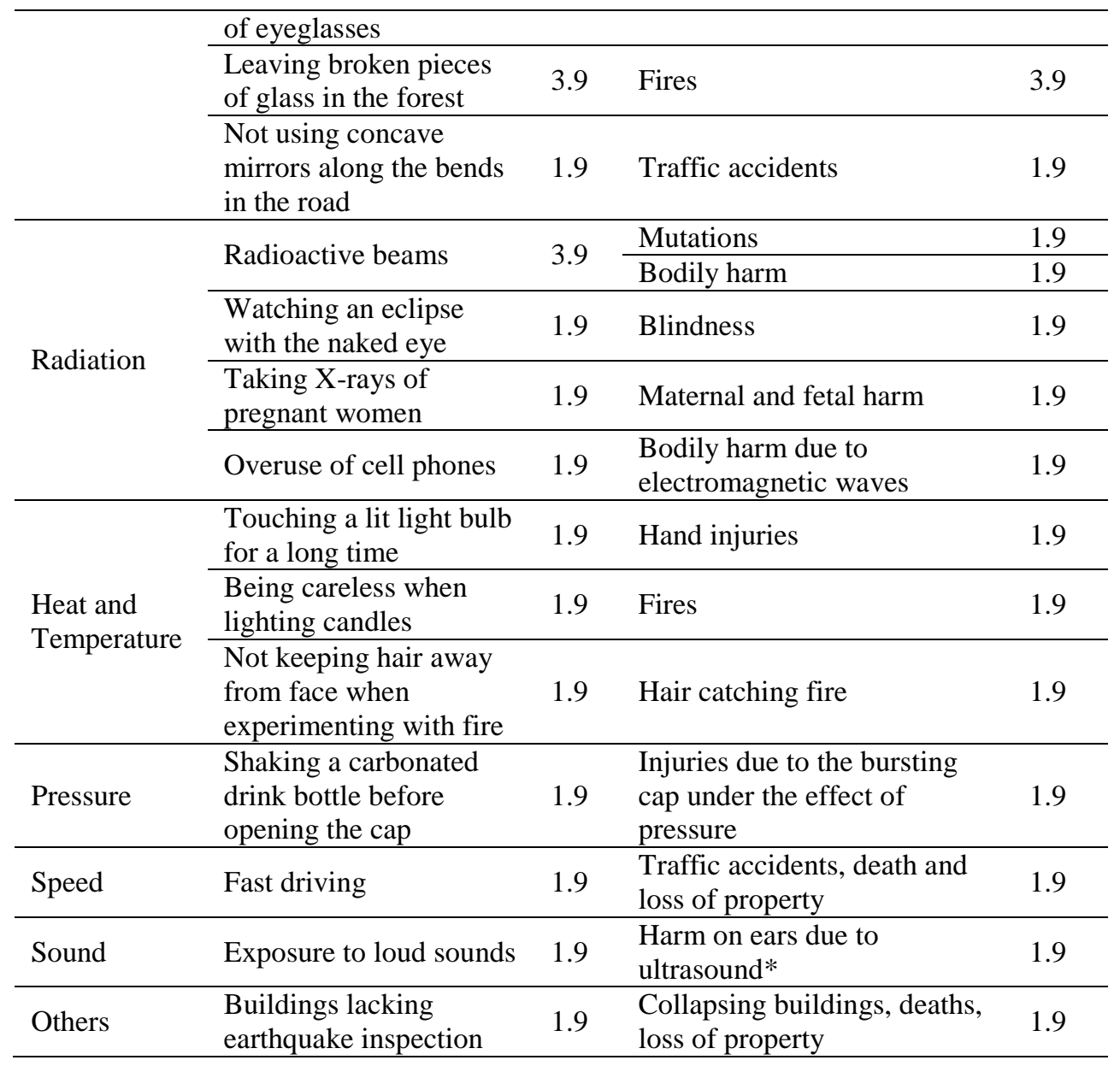

According to Table 2, the participants' daily life-threatening situations were mostly associated with electricity as related to their physics knowledge. The findings showed that several participants provided explanations that contradicted scientific notions. For example, $12.4 \%$ of the preservice teachers who gave the example of electric shock $(68.6 \%)$ stated that changing light bulbs while the switch was open was hazardous. Also, $1.9 \%$ of preservice teachers thought loud sounds were the same as ultrasound. Similarly, $1.9 \%$ thought that friction depended on surface area. These explanations indicated misconceptions. Additionally, several reasons (5.9\%) were given regarding the term, "friction," which they said decreased with ice instead of referring to the friction coefficient or frictional force. Also, several participants offered irrelevant responses: touching electric wires $(3.9 \%)$, cultivating soil on sloping land (1.9\%), friction experiments $(1.9 \%)$, expansion of wires in summer (1.9\%), and plugging in electrical appliances $(1.9 \%)$. 


\section{Acta Educationis Generalis \\ Volume 12, 2022, Issue 1}

Table 3 shows details from the participants' responses related to the theme of electricity which is the most dominant theme in physics.

Table 3

Details related to the categories of the theme electricity

\begin{tabular}{|c|c|c|c|}
\hline Theme & Categories & Sub-categories & $\underline{\%}$ \\
\hline \multirow{13}{*}{ Electricity } & \multirow{8}{*}{ Electric Shock } & - Touching a switch with wet hands & $1 \overline{5.7}$ \\
\hline & & $\begin{array}{l}\text { - Changing light bulbs without taking } \\
\text { precautions }\end{array}$ & 12.4 \\
\hline & & - Standing under a tree when there is & 8.5 \\
\hline & & lightning and thunder & 85 \\
\hline & & 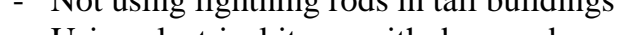 & \\
\hline & & $\begin{array}{l}\text { wires } \\
\text { wing entical ilems with damaged }\end{array}$ & 0.5 \\
\hline & & - Using switches without a covering & 8.5 \\
\hline & & - Inserting conductors into the switch & 6.5 \\
\hline & \multirow{5}{*}{$\begin{array}{l}\text { Problems with } \\
\text { Electrical } \\
\text { Items }\end{array}$} & - Leaky electrical devices & 5.9 \\
\hline & & - Electrical devices with short circuits & 5.2 \\
\hline & & - Overheating of electrical appliances left & 3.3 \\
\hline & & plugged in too long & \\
\hline & & - Electrical devices exposed to high voltage & 3.3 \\
\hline
\end{tabular}

The reasons preservice teachers offered in the context of physics-related cases were mostly associated with the harm to human health, such as deaths and injuries. Also, fires, traffic accidents, loss of property were other reasons behind the examples they provided.

\subsection{Findings about chemistry}

Table 4 presents the preservice science teachers' examples of life-threatening situations in everyday life in the context of their chemistry knowledge and the reasons they provided these examples.

Table 4

Turkish preservice teachers' claims regarding daily life-threatening situations in the context of chemistry knowledge

\begin{tabular}{|c|c|c|c|c|}
\hline \multirow[t]{2}{*}{ Themes } & Categories & $\underline{\%}$ & Because it might cause... & $\frac{\%}{2}$ \\
\hline & $\begin{array}{l}\text { Not taking safety } \\
\text { precautions while } \\
\text { working with }\end{array}$ & 74.5 & $\begin{array}{l}\text { Health problems/deaths } \\
\text { Physical damage when gloves, } \\
\text { masks or coats are not worn. }\end{array}$ & $\begin{array}{l}43.1 \\
23.5\end{array}$ \\
\hline \multirow[t]{3}{*}{ Chemicals } & chemicals at home, in & & Explosions/fires & 3.9 \\
\hline & the lab or outside & & Loss of property & 3.9 \\
\hline & $\begin{array}{l}\text { Breathing hazardous } \\
\text { chemicals }\end{array}$ & 23.5 & $\begin{array}{l}\text { Harms on health/lungs } \\
\text { Poisoning }\end{array}$ & $\begin{array}{l}19.6 \\
3.9\end{array}$ \\
\hline
\end{tabular}




\section{Acta Educationis Generalis \\ Volume 12, 2022, Issue 1}

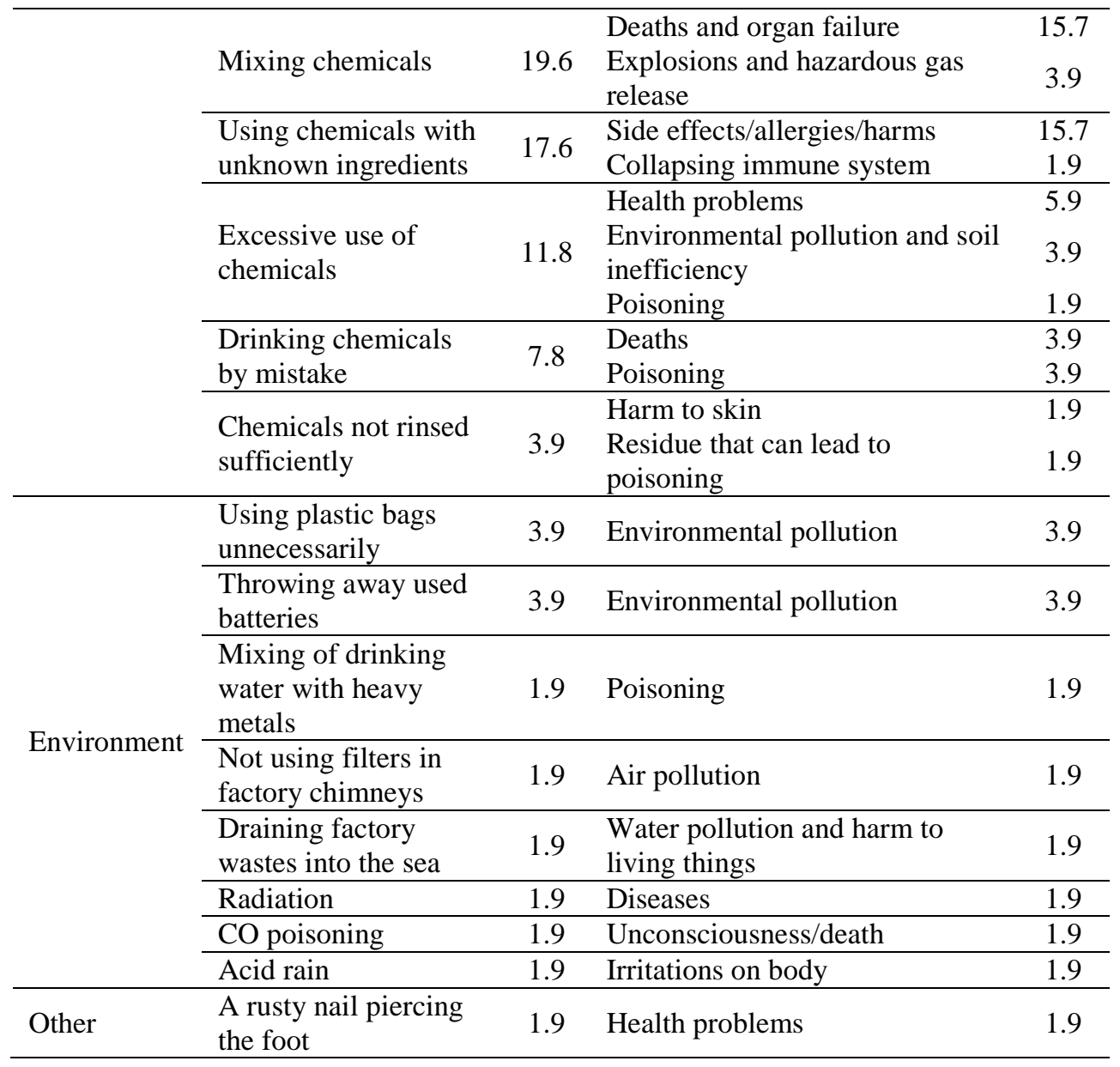

Table 4 summarizes the preservice science teachers' claims under two themes in the context of chemistry as well as the case of a rusty nail piercing the foot that is shown under "Other." Details of the cases shown as examples as related to the most dominant theme of chemicals are demonstrated in Table 5.

Table 5

Details of the categories of the theme chemicals

\begin{tabular}{|c|c|c|c|}
\hline Theme & Categories & Sub-categories & $\%$ \\
\hline Chemicals & $\begin{array}{l}\text { Not taking safety } \\
\text { precautions while working } \\
\text { with the chemicals at home, } \\
\text { in the lab or outside }\end{array}$ & $\begin{array}{l}\text { - Touching chemicals without gloves } \\
\text { - Leaving the cap of formaldehyde } \\
\text { bottles open } \\
\text { - Keeping chemicals in places where } \\
\text { children could reach }\end{array}$ & 39.2 \\
\hline
\end{tabular}




\begin{tabular}{|c|c|c|}
\hline $\begin{array}{l}\text { Breathing hazardous } \\
\text { chemicals }\end{array}$ & $\begin{array}{ll}\text { - } & \text { Hydrochloric acid } \\
\text { - } & \text { Mercury vapor }\end{array}$ & $\begin{array}{c}15.7 \\
7.8\end{array}$ \\
\hline $\begin{array}{l}\text { Using chemicals with } \\
\text { unknown ingredients }\end{array}$ & $\begin{array}{l}\text { - } \text { Medicines } \\
\text { - Cosmetics } \\
\text { - } \text { Herbal teas }\end{array}$ & $\begin{array}{l}7.8 \\
6.5 \\
3.3\end{array}$ \\
\hline Excessive use of chemicals & $\begin{array}{ll}\text { - } & \text { Fertilizers } \\
\text { - } & \text { Pesticides } \\
\text { - } & \text { Cleaning substances }\end{array}$ & $\begin{array}{l}4.6 \\
3.9 \\
3.3\end{array}$ \\
\hline $\begin{array}{l}\text { Drinking chemicals by } \\
\text { mistake }\end{array}$ & $\begin{array}{l}\text { - Poisonous substances } \\
\text { - Acids } \\
\text { - Bases } \\
\end{array}$ & $\begin{array}{l}3.9 \\
2.6 \\
1.3\end{array}$ \\
\hline $\begin{array}{l}\text { Chemicals not rinsed } \\
\text { sufficiently }\end{array}$ & $\begin{array}{l}\text { - Cosmetics not cleaned from skin } \\
\text { properly } \\
\text { - Residues of detergents not removed } \\
\text { from glasses }\end{array}$ & $\begin{array}{l}1.9 \\
1.9\end{array}$ \\
\hline
\end{tabular}

The reasons the participants provided generally signified their awareness of health problems such as irritations, allergies, side effects and environmental pollution in the context of chemistry-related cases. On the other hand, several participants provided irrelevant responses such as spending too much ATP $(1.9 \%)$ and squeezing lemon juice into mineral water (1.9\%).

\subsection{Findings related to biology}

Table 6 presents the preservice science teachers' examples along with their reasons for suggesting life-threatening cases in everyday life that can be explained in the context of a knowledge of biology.

\section{Table 6}

Turkish preservice teachers' claims regarding life-threatening situations in daily life in the context of biology knowledge

\begin{tabular}{|c|c|c|c|c|}
\hline Themes & Categories & & it $\quad$ might & \\
\hline \multirow{4}{*}{ Environment } & \multirow{4}{*}{ Damaging nature } & \multirow{4}{*}{33.3} & $\frac{\text { cause... }}{\text { Extinction }}$ & 118 \\
\hline & & & & 9.8 \\
\hline & & & Health problems & 7.8 \\
\hline & & & $\begin{array}{l}\text { Decrease in } \mathrm{O}_{2} \text { amount } \\
\text { due to forest damage }\end{array}$ & 3.9 \\
\hline \multirow{3}{*}{ Food } & $\begin{array}{l}\text { Consuming food } \\
\text { inappropriately }\end{array}$ & 31.4 & Health problems & 31.4 \\
\hline & Consuming Genetically & & Diseas & 11.8 \\
\hline & $\begin{array}{l}\text { Modified Organisms } \\
\text { (GMOs)/prepared/packaged }\end{array}$ & 25.5 & $\begin{array}{l}\text { Negative effects on } \\
\text { hormones }\end{array}$ & 9.8 \\
\hline
\end{tabular}




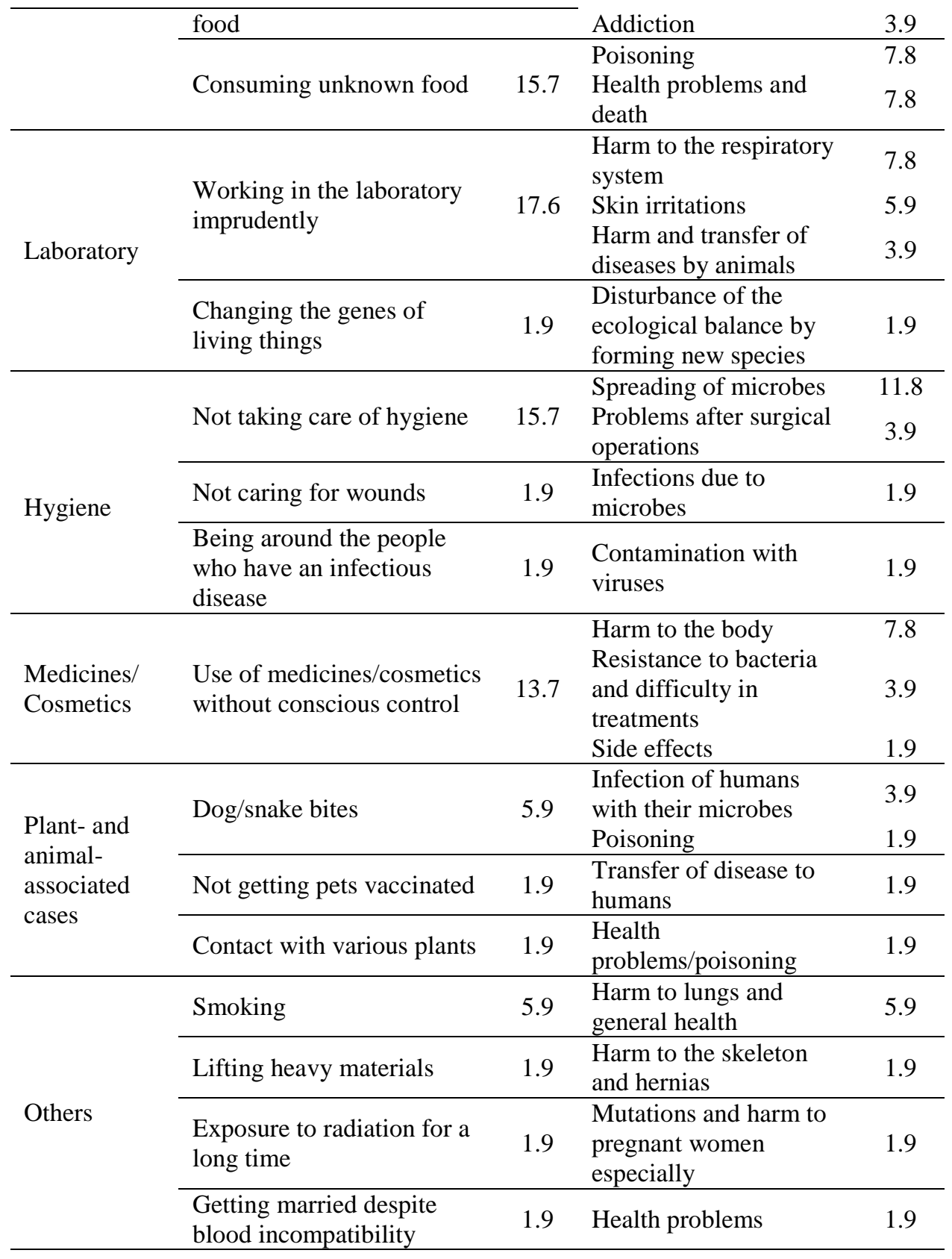

According to Table 6, the cases of preservice teachers' daily life-threatening situations that could be associated with biology knowledge were mostly related to the themes of environment and food. Table 7 shows the details of the theme of food. 


\section{Acta Educationis Generalis \\ Volume 12, 2022, Issue 1}

Table 7

Details of the theme of food

\begin{tabular}{|c|c|c|c|}
\hline Theme & Categories & $\underline{\text { Sub-categories }}$ & $\underline{\%}$ \\
\hline \multirow{10}{*}{ Food } & \multirow{6}{*}{$\begin{array}{l}\text { Consuming food } \\
\text { inappropriately }\end{array}$} & - Too much sugar/salt & 10.5 \\
\hline & & - Eating food after its best-before date & 6.5 \\
\hline & & $\begin{array}{l}\text { - Eating vegetables/ fruits without washing } \\
\text { them properly }\end{array}$ & 5.2 \\
\hline & & - Eating yoghurt with fish & 3.9 \\
\hline & & - Drinking water that has not been analyzed & 3.3 \\
\hline & & - Going to sleep just after having a meal & 1.9 \\
\hline & Consuming & - Eating GMOs & 13.1 \\
\hline & $\begin{array}{l}\text { GMOs/prepared/ } \\
\text { packaged food }\end{array}$ & $\begin{array}{l}\text { - Eating prepared/packaged food sold at the } \\
\text { markets }\end{array}$ & 12.4 \\
\hline & Consuming & - Several types of mushrooms & 9.8 \\
\hline & unknown food & - Unknown fruits/ vegetables & 5.9 \\
\hline
\end{tabular}

As in the previous cases mentioned, the reasons the participants provided were associated with health problems. When examined in detail, it was seen that the participants asserted that consuming food inappropriately was a daily lifethreatening situation because this might cause obesity, high blood pressure, insulin resistance, diabetes, fatty liver, problems in digestion and intestinal parasites. On the other hand, $1.9 \%$ of the participants made irrelevant claims such as working with $\mathrm{Z}$ bacteria.

\section{Discussion}

The presented study revealed the various claims of preservice science teachers regarding daily life-threatening situations. The study focused on the association of scientific knowledge with daily life, which is one of the aims of science education. The association of science with daily life has an important place in cognitive and affective development and improving students' skills (Çepni et al. (2017). Also, preservice teachers made connections with various health issues. The research has thus introduced a different approach to scientific knowledgedaily life association studies. In this way, the study has made contributions to health education studies in science education which Harrison (2005) has said have been ignored. Additionally, the introduction of "safety and health issues" into the school curriculum has been indicated to be essential at all levels to prepare students for future life (Ižová, 2011).

Considering the results of the study, it is obvious that various situations asserted by the participants gathered under specific categories at $10 \%$ and above, whereas the others remained below this rate. The cases with percentages of $10 \%$ and above were accepted as being the dominant responses. The next part of the paper 


\section{Acta Educationis Generalis \\ Volume 12, 2022, Issue 1}

will focus on comparisons generally based on results yielding rates of $10 \%$ and over.

The cases that preservice teachers brought up as life-threatening situations in the context of physics knowledge were dominant in the categories of electric shock and problems with electric items. In another study, it was also found that Finnish high school students were interested in the effect of strong electric shocks on the human body (Uitto, Juuti, Lavonen, \& Meisalo, 2006). On the other hand, the participants pointed out a number of claims with relatively lower percentages. One of these claims pointed to the impact of earthquakes causing injuries, deaths and loss of property because of improperly reinforced buildings. In his study, Bulut (2020) highlighted the importance of providing pre-school children with disaster education and disaster awareness since they will be the builders of the future. Also, the present study revealed the extensive use of cell phones as a hazardous situation among the participants' claims. However, another study reported that more than $70 \%$ of preservice teachers stated they were not concerned about the impacts of radiation from the frequent use of cell phones (Ratnapradipa, Rhodes, \& Brown, 2011). Moreover, the effect of radiation on the human body was also determined to be a subject that students found interesting to learn about in Uitto et al.'s (2006) study.

The results obtained from of the claims of the participants that depended on knowledge of physics also demonstrated several misconceptions. Firstly, the preservice teachers revealed a misconception related to open and closed circuits that might have stemmed from the language structure of Turkish. The participants thought that the circuit flowed when the switch was open. This finding was consistent with the literature (Önder, Şenyiğit, \& Sılay, 2017). Also, they perceived loud sounds were the same as ultrasound and indicated that ultrasound was harmful to the ears. The findings revealed another misconception and showed similarity with one of the results of a previous research article (Adekanmi et al., 2012). Adekanmi et al.'s (2012) study conducted with Nigerian women indicated that several participants thought ultrasound was injurious to health. Moreover, some preservice teachers had insufficient knowledge and could not explain frictional force and the friction coefficient. Instead, they preferred to use the term "friction" in indicating that ice caused less friction. This result was similar to the finding of Sari, Ramdhani and Surtikanti (2019), which also showed that the participants' responses referred to friction but did not contain frictional force. Furthermore, the preservice teachers highlighted a relationship between friction and the surface area of a shoe whereas friction is independent of the surface area of an object.

When the claims of the preservice teachers regarding chemistry were investigated, the majority of their claims were seen to be related to their concerns about the safety precautions in the laboratory, at home or in other environments. This result might have been influenced by laboratory studies in chemistry courses and in the comprehension regarding the significance of 


\section{Acta Educationis Generalis \\ Volume 12, 2022, Issue 1}

working properly with chemicals. Miller, Heideman, and Greenbowe (2000) stated that university students must also bear responsibility for dealing with experimental risks as well as for increasing regulatory actions designed to minimize hazardous situations. Also, breathing hazardous chemicals, using chemicals with unknown ingredients, mixing various chemicals and the excessive use of chemicals were among the dominant responses. Similar to the responses of the preservice teachers in the present study, Finnish high school students were found to be interested in the effects of some cosmetics on skin such as lotions and creams, and in pesticides and artificial fertilizers (Uitto et al., 2006). On the other hand, various cases were mentioned at lower percentages, such as not using filters in factory chimneys, using plastic bags unnecessarily, radiation and acid rain. Yet, the participants paid attention to chemistryenvironment concerns as well as to chemistry-associated human health concerns. A similar finding was also determined in the study of Mandler et al. (2012).

According to the results of the present study, when the numbers of the categories were considered, among the three branches considered, more dominant cases were found to belong to biology $(n=7)$, which was followed by chemistry $(n=5)$ and physics $(\mathrm{n}=2)$. However, this finding contradicted what was obtained from Balkan-Kıyıcı and Aydoğdu's (2011) research. Their research reported that teacher candidates were more likely to associate their physics knowledge with daily life; their examples of lesser dominance were within the scope of chemistry knowledge and biology knowledge.

The results of the study in the context of biology revealed that consuming GMOs was identified as a hazardous situation. However, another study conducted with preservice teachers in the U.S. showed that participants had a high tendency to accept altering the genes of fruits to make them tasty or adding genes to plants to increase their nutritional value (Chabalengula, Mumba, \& Chitiyo, 2011). On the other hand, the present study indicated various lower percentage cases such as getting married despite blood incompatibility, exposure to radiation, being around people with an infectious disease, not caring for wounds, lifting heavy materials, smoking, contact with some plants, dog/snake bites and not getting pets vaccinated. The study conducted by Uitto et al. (2006) also showed similar interests of Finnish high school students, such as the effect of tobacco, dangerous and threatening animals, poisonous plants, epidemics and diseases, reproduction and gene technology.

While various situations were suggested by the participants, other situations seemed to be ignored. These might be illustrated as decompression sickness in the realm of physics, global warming/climate change, keeping plastic water bottles under sunlight, firedamp explosions in the realm of chemistry and travelling to different locations without getting properly vaccinated and having computer tomography in the context of biology. The cases of decompression sickness, firedamp explosions (Yadigaroğlu et al., 2017) and global climate change (Ratnapradipa et al., 2011) were seen to be investigated in previous 


\section{Acta Educationis Generalis \\ Volume 12, 2022, Issue 1}

research. On the other hand, the study showed that radiation was addressed in the three branches of science among the preservice teachers' responses. However, the percentages of the claims related to radiation were relatively low. This might be due to the relatively low awareness levels of students as reported in a previous piece of research (Dolu \& Ürek, 2015).

When the participants' reasons were considered, it was seen that their focus was mostly on health problems. It might be concluded that the participants are aware of various health problems. Also, Krásna's (2014) study indicated that the majority of Slovakian secondary school students perceived the concept of health as the most important value in life and for this reason they also mentioned healthy diet, healthy food, no smoking and hygiene as elements of maintaining an individual's healthy condition. The findings in the present study might be attributed to the effect of the participants' educational status as in the study by Ross and Mirowsky (2011). This was relatively more obvious in the reasons they offered in the context of biology. A number of health problems, from insulin resistance to hormonal disorders, were mentioned by the participants. This finding was consistent with the results of previous literature which detected several diseases in preservice teachers' responses in terms of connecting biology to daily life (Çepni et al., 2017; Mercan et al., 2019; Uitto et al., 2006). Also, the participants mentioned poisoning and irritations in the respiratory system in the context of chemistry. On the other hand, they showed a more general approach when talking about health problems in the context of physics, mentioning deaths and injuries in their examples. Yet they talked about more detailed cases such as harm to the eyes due to eclipses and using the wrong type of eyeglasses in the context of their physics knowledge. Furthermore, the participants were found to mention environmental problems as the reason for some of the life- threatening everyday cases they suggested. This finding was consistent with Çepni et al.'s (2017) study. Science teacher candidates in their study also mentioned environmental pollution at the highest percentage in terms of connecting biology to daily life in an environmental science course. The concerns of the participants related to environmental health issues paralleled the attitudes of American teacher candidates (Ratnapradipa et al., 2011). The researchers showed that $90 \%$ of the participants considered what effects environmental health issues would have on their families and on themselves.

\section{Conclusion}

To conclude, the results of the present study indicated that third-year science teaching students associated their scientific knowledge with daily lifethreatening situations at various levels and they were aware of health and environmental issues that affected their suggested cases. However, there were also gaps in their scientific knowledge-daily life association. Additionally, several misconceptions were encountered in their explanations. A limitation of 


\section{Acta Educationis Generalis \\ Volume 12, 2022, Issue 1}

the study was that the findings were obtained from only three state universities in Turkey.

The results of the study are recommended for utilization in designing units based on the suggested cases for various undergraduate courses such as Environmental Science or Science Teaching Laboratory Practices taught at the education faculties. As explained by Uitto et al. (2006), students' interests might trigger better science learning. Hence, science educators might find it useful in their context-based approaches, to consider in detail in their courses the various contributions of the students in the study regarding the topics that interested them. It will also be beneficial to consider situations that have not been mentioned by the participants. This will provide the opportunity to enrich the content of some courses and make them more attractive to students. Currently relevant topics could be discussed in the classroom environment in order to raise the awareness levels of preservice teachers. Finally, similar investigations might be conducted in different countries so that it might be possible to make further comparisons.

\section{Acknowledgement}

This research was supported by Balıkesir University Scientific Research Projects, 2019/093.

\section{References}

Adekanmi, A. J., Morhason-Bello, I. O., Atalabi, O. M., Adedokun, B. O., Adeniji-Sofoluwe, A. A., \& Marinho, A. O. (2012). Misconception about ultrasound among Nigerian women attending specialist and tertiary health institutions in Ibadan. Tropical Journal of Obstetrics and Gynaecology, 29(2), 71-76.

Balkan-Kıyıcı, F., \& Aydoğdu, M. (2011). Fen bilgisi öğretmen adaylarının günlük yaşamları ile bilimsel bilgileri ilişkilendirebilme düzeylerinin belirlenmesi. Necatibey Eğitim Fakültesi Elektronik Fen ve Matematik Ĕgitimi Dergisi (EFMED), 5(1), 43-61.

Brkich, K. L. (2014). Urban fifth graders' connections-making between formal earth science content and their lived experiences. Cultural Studies of Science Education, 9, 141-164. https://doi.org/10.1007/s11422-013-9505-8

Bulut, A. (2020). Raising awareness of disaster and giving disaster education to children in preschool education period. Acta Educationis Generalis, 10(2), 162-179. https://doi.org/10.2478/atd-2020-0016

Büyüköztürk, Ş., Kılıç Çakmak, E., Akgün, Ö. E., Karadeniz, Ş., \& Demirel, F. (2010). Bilimsel araştırma yöntemleri. Ankara: PegemA.

Cengiz, E., \& Ayvacı, H. Ş. (2017). Examining fifth-grade students' level of associating some daily-life events with "changes of state". Asia-Pacific Forum on Science Learning and Teaching, 18(1), 1-20.

Chabalengula, V. M., Mumba, F., \& Chitiyo, J. (2011). American elementary education preservice teachers' attitudes towards biotechnology processes. International Journal of Environmental \& Science Education, 6(4), 341-357.

Chowdhury, M. A. (2013). Incorporating a soap industry case study to motivate and engage students in the chemistry of daily life. Journal of Chemical Education, 90, 866-872. http://dx.doi.org/10.1021/ed300072e 


\section{Acta Educationis Generalis \\ Volume 12, 2022, Issue 1}

Çelik, H., Başer Baykal, N., \& Kılıç Memur, H. N. (2020). Nitel veri analizi ve temel ilkeleri. Journal of Qualitative Research in Education, 8(1), 379-406. https://doi.org/10.14689/issn.2148-2624.1.8c.1s.16m

Çepni, S., Ülger, B. B., \& Ormanc1, Ü. (2017). Pre-service science teachers' views towards the process of associating science concepts with everyday life. Journal of Turkish Science Education, 14(4), 1-15. https://doi.org/10.12973/tused.10208a

Çimer, A. (2012). What makes biology learning difficult and effective: Students' views. Educational Research and Reviews, 7(3), 61-71. https://doi.org/10.5897/ERR11.205

Deboer, G. E. (2000). Scientific literacy: Another look at its historical and contemporary meanings and its relationship to science education reform. Journal of Research in Science Teaching, 37(6), 582-601.

Demircioğlu, H., Demircioğlu, G., Ayas, A., \& Kongur, S. (2012). Onuncu sınıf öğrencilerinin fiziksel ve kimyasal değişme ile ilgili teorik ve uygulama bilgilerinin karşılaştırılması. Journal of Turkish Science Education, 9(1), 162-185.

Demircioğlu, H., Demircioğlu, G., \& Çalık, M. (2009). Investigating the effectiveness of storylines embedded within a context-based approach: The case for the periodic table. Chemistry Education Research and Practice, 10, 241-249. https://doi.org/10.1039/b914505m

Dolu, G., \& Ürek, H. (2015). Lisansüstü öğrenciler elektromanyetik kirlilik konusunda yeterince bilinçli mi? Necatibey Eğitim Fakültesi-Elektronik Fen ve Matematik Eğitimi Dergisi, 9(1), 165-183. https://doi.org/10.17522/nefefmed.36630

Elmas, R., \& Geban, Ö. (2016). Bağlam temelli kimya eğitiminin 9. sınıf öğrencilerinin temizlik maddeleri konusunu öğrenmelerine ve çevreye karşı tutumlarına etkisinin incelenmesi. Eğitim ve Bilim, 41(185), 33-50. https://doi.org/10.15390/EB.2016.5502

Geršicová, Z., \& Barnová, S. (2018). Personal and social training as a part of class teachers' lifelong learning. Acta Educationis Generalis, 8(2), 24-39. https://doi.org/10.2478/atd-20180009

Harrison, J. K. (2005). Science education and health education: Locating the connections. Studies in Science Education, 41(1), 51-90. https://doi.org/10.1080/03057260508560214

Hsieh, H.-F., \& Shannon, S. E. (2005). Three approaches to qualitative content analysis. Qualitative Health Research, 15(9), 1277-1288. https://doi.org/10.1177/1049732305276687

Ižová, K. (2011). The safety and hygiene at work in a school curriculum. Acta Technologica Dubnicae, 1(2), 61-65. https://doi.org/10.1515/atd-2015-0047

King, D., Bellocchi, A., \& Ritchie, S.M. (2008). Making connections: Learning and teaching chemistry in context. Research in Science Education, 38, 365-384. https://doi.org/10.1007/s11165-007-9070-9

Krásna, S. (2014). Subjective understanding and individual interpretation of the life value "health" by the second-year students of lower secondary schools and of the first- and second-year students of upper secondary schools in Slovakia. Acta Technologica Dubnicae, 4(2), 1-18. https://doi.org/10.1515/atd-2015-0001

Kutu, H., \& Sözbilir, M. (2011). Yaşam temelli arcs öğretim modeliyle 9. sınıf kimya dersi "hayatımızda kimya" ünitesinin öğretimi. Ondokuz Mayıs Üniversitesi Eğitim Fakültesi Dergisi, 30(1), 29-62.

Mandler, D., Mamlok-Naaman, R., Blonder, R., Yayon, M., \& Hofstein, A. (2012). High-school chemistry teaching through environmentally oriented curricula. Chemical Education Research and Practice, 13, 80-92.

Mansour, N. (2009). Science-technology-society (STS) a new paradigm in science education. Bulletin of Science, Technology \& Society, 29(4), 287-297. https://doi.org/10.1177/0270467609336307

Mercan, G., Gürlen, E., \& Köseoğlu, P. (2019). Biyoloji öğretmen adaylarının bilimsel bilgileri günlük yaşamları ile ilişkilendirebilme durumlarının incelenmesi. Ĕgitimde Nitel Araştırmalar Dergisi, 7(1), 319-343. https://doi.org/10.14689/issn.2148-2624.1.7c1s.15m 


\section{Acta Educationis Generalis \\ Volume 12, 2022, Issue 1}

Miles, M. B., \& Huberman, A. M. (1994). Qualitative data analysis an expanded sourcebook (2 ${ }^{\text {nd }}$ edition). California: Sage Publications.

Miller, G. J., Heideman, S. A., \& Greenbowe, T. J. (2000). Introducing proper chemical hygiene and safety in the general chemistry curriculum. Journal of Chemical Education, 77(9), 11851187.

Önder, F., Şenyiğit, Ç., \& Sılay, İ. (2017). The effects of misconceptions on pre-service teachers' ability to constructing simple electric circuits. European Journal of Physics Education, 8(1), $1-10$.

Ratnapradipa, D., Rhodes, D. L., \& Brown, S. L. (2011). Evaluating pre-service teacher workforce: environmental health knowledge, attitude, and behavior. Online Journal of Workforce Education and Development, 5(1), 1-18.

Ross, C. E., \& Mirowsky, J. (2011). The interaction of personal and parental education on health. Social Science \& Medicine, 72, 591-599. https://doi.org/10.1016/j.socscimed.2010.11.028

Roth, W.-M., \& Lee, S. (2004). Science education as/for participation in the community. Science Education, 88, 263-291.

Sari, D. R., Ramdhani, D., \& Surtikanti, H. K. (2019). Analysis of elementary school students' misconception on force and movement concept. Journal of Physics: Conference Series, 1157, 1-5. https://doi.org/10.1088/1742-6596/1157/2/022053

Talanquer, V. (2013). Chemistry education: Ten facets to shape us. Journal of Chemical Education, 90, 832-838. http://dx.doi.org/10.1021/ed300881v

Taşdemir, A., \& Demirbaş, M. (2010). İlköğretim öğrencilerinin fen ve teknoloji dersinde gördükleri konulardaki kavramları günlük yaşamla ilişkilendirebilme düzeyleri. Uluslararası İnsan Bilimleri Dergisi, 7(1), 124-148.

Tytler, R. (2007). Re-imagining science education: Engaging students in science for Australia's future. Camberwell, VIC: Australian Council for Educational Research.

Uğraş, M., Aydemir, S., \& Asiltürk, E. (2017). Analysis of pre-service science teachers' level of associating their chemistry knowledge with daily life and the relationship between these levels and their attitudes towards teaching science. Journal of Human Sciences, 14(4), 45394545. https://doi.org/10.14687/jhsv14i4.5105

Uitto, A., Juuti, K., Lavonen, J., \& Meisalo, V. (2006). Students' interest in biology and their outof-school experiences. Journal of Biological Education, 40(3), 124-129. https://doi.org/10.1080/00219266.2006.9656029

Yadigaroğlu, M., Demircioğlu, G., \& Demircioğlu, H. (2017). Fen bilgisi öğretmen adaylarının kimya bilgilerini günlük hayatla ilişkilendirebilme düzeyleri. Ege Eğitim Dergisi, 18(2), 795-812.

Yıldırım, A., \& Şimşek, H. (2016). Sosyal bilimlerde nitel araştırma yöntemleri. Ankara: Seçkin Yayıncilik. 